\title{
A comparative study of viruses associated with acute haemorrhagic conjunctivitis
}

\author{
P. G. HIgGins, R. J. SCOTT ${ }^{1}$, PATRICIA M. DAVIES, AND D. R. GAMBLE \\ From the Virus Reference Laboratory, Central Public Health Laboratory, Colindale, London, and the \\ Public Health Laboratory, West Park Hospital, Epsom
}

SYNOPSIS Seven representative isolates from six outbreaks of acute haemorrhagic conjunctivitisin were shown to have the characteristics of enteroviruses. Two viruses differed from the remaining $A$ five isolates in producing paralysis in suckling mice and being resistant to 2-hydroxybenzyl-benzi-î midazole. These two viruses were also closely related antigenically and distinct from the other five viruses which were serologically similar to each other.

Neither group of viruses was inhibited by antisera to the known enteroviruses and they probably represent two new enterovirus types one related to the Coxsackie A viruses and the other to the echoviruses.

In recent years a picornavirus has been found in association with a number of epidemics of acute haemorrhagic conjunctivitis (Lim and Yin-Murphy, 1971; Kono, Sasagawa, Ishii, Sugiura, Ochi, Matsumiya, Uchida, Kameyama, Kaneko, and Sakurai, 1972; Jones, 1972; Bourdieu, 1973; Higgins and Scott, 1973). The picornaviruses isolated from patients with conjunctivitis during these outbreaks have not always possessed the same characteristics, and differences in the requirements for their isolation (Higgins and Scott, 1973), their pathogenicity for suckling mice, and their antigenicity (Yin-Murphy, 1973) have been observed.

This paper describes the results of comparative studies of certain characteristics of seven representative viruses isolated from patients during six different outbreaks of acute haemorrhagic conjunctivitis.

\section{Materials}

Two serologically distinct viruses, HK $3751 / 71$ and HK 3454/71, were received from Dr W. K. Chang who isolated them from patients with conjunctivitis during an epidemic in Hong Kong in 1971.

The virus YC 648/71 was supplied by Professor R. Kono and was isolated in 1971 from a patient

'Present address: Public Health Laboratory, Central Middlesex Hospital, Acton Lane, Park Royal, London NW10 7NT

Received for publication 6 February 1974. with conjunctivitis in Japan (Kono et al, 1972). The remaining four viruses were isolated at the Virus Reference Laboratory, Colindale. Two viruses were? selected from a number recovered from material sent by Dr M. Yin-Murphy and were representative $\triangle$ of the isolates made from cases presenting duringo each of two outbreaks of conjunctivitis in Singapore, one in 1970 and the other in 1971 (Lim and YinMurphy, 1973). The other two viruses studied were: isolated in organ culture from material supplied용 by Professor B. Jones and were typical of the virusesencountered in the study of outbreaks of conjuncti- 3 . vitis in England in 1971 and in Djakarta in 1972 (Higgins and Scott, 1973).

Each virus was grown in cultures of $\mathrm{HeLa}$ cellso (Conant and Hamparian, 1968) which were frozen and thawed when the cytopathic effect was complete. The tissue culture fluid was clarified by low speed $\bar{N}$. centrifugation, divided into aliquots, and stored ato $-40^{\circ} \mathrm{C}$ for use in all the tests.

\section{Methods and Results}

A number of biological, physicochemical, and antigenic properties were determined for each of thes? viruses. However, as it became apparent that the viruses could be divided into two groups, certain ${ }_{0}^{-}$ characteristics, eg, virus particle size and plaque $\vec{\Phi}$ morphology, were established on a single repre- $\frac{?}{\mathbb{D}}$ sentative virus from each group only. The results $\varrho$ are summarized in table $I$. 


\begin{tabular}{|c|c|c|}
\hline & \multicolumn{2}{|l|}{ Group } \\
\hline & $I$ & $\boldsymbol{I I}$ \\
\hline Strain & $\begin{array}{l}\text { Singapore } 1970 \\
\text { HK } 3751 / 71\end{array}$ & $\begin{array}{l}\text { Japan } 1971 \\
\text { England } 1971 \\
\text { Singapore } 1971 \\
\text { Djakarta } 1972 \\
\text { HK 3454/71 }\end{array}$ \\
\hline \multirow{2}{*}{$\begin{array}{l}\text { Titre of virus cultured in HeLa cells } \\
\text { Adaptation to monkey kidney tissue } \\
\text { culture } \\
\text { Size }\end{array}$} & $10^{7.5} \mathrm{TCID}_{\mathrm{so}} / \mathrm{ml}$ & $10^{5.5} \mathrm{TCID}_{50} / \mathrm{ml}$ \\
\hline & $\begin{array}{l}\text { With difficulty } \\
26.9 \mathrm{~nm} \\
\text { (HK } 3751 / 71)\end{array}$ & $\begin{array}{l}\text { Rapidly } \\
26 \cdot 5 \mathrm{~nm} \\
\text { (Singapore 1971) }\end{array}$ \\
\hline Plaque morphology & $\begin{array}{l}\text { Small, irregular } \\
\text { (HK 3751/71) }\end{array}$ & $\begin{array}{l}\text { Small, irregular } \\
\text { (Singapore 1971) }\end{array}$ \\
\hline Ether & Resistant & Resistant \\
\hline Acid & Resistant & Resistant \\
\hline $\begin{array}{l}\text { Sodium deoxycholate } \\
\text { Presence of } \mathrm{M} \mathrm{MgCl} \text { at } 50^{\circ} \mathrm{C} \text { for }\end{array}$ & Resistant & Resistant \\
\hline one hour & Inactivation prevented & Inactivation prevented \\
\hline 5-Iododeoxyuridine & Resistant & Resistant \\
\hline 2-Hydroxybenzyl-benzimidazole & Resistant & Sensitive \\
\hline $\begin{array}{l}\text { Buoyant density in } \mathrm{CsCl}_{\mathbf{2}} \\
\text { Haemagglutinin }\end{array}$ & $\begin{array}{l}1 \cdot 34 \mathrm{~g} / \mathrm{ml} \\
\text { Absent }\end{array}$ & $\begin{array}{l}1 \cdot 34 \mathrm{~g} / \mathrm{ml} \\
\text { Absent }\end{array}$ \\
\hline Suckling mouse inoculation & Paralysis & Non-pathogenic \\
\hline Serological relationship & $\begin{array}{l}\text { Antigenically related to each other but } \\
\text { distinct from members of group II }\end{array}$ & $\begin{array}{l}\text { Antigenically related to each other but } \\
\text { distinct from members of group I }\end{array}$ \\
\hline
\end{tabular}

Table I Characteristics of seven representative viruses associated with six outbreaks of acute haemorrhagic conjunctivitis

GROWTH IN TISSUE CULTURE

All seven viruses could be grown in cultures of rhesus monkey kidney, $\mathrm{HeLa}$ cells, the $\mathrm{WI}_{38}$ strain of human embryo diploid fibroblasts and human embryo kidney. The Singapore 1970 and HK 3751/71 viruses adapted less readily to primary monkey kidney than the remaining five viruses and all seven strains grew best in HeLa cells. The infectivity of the

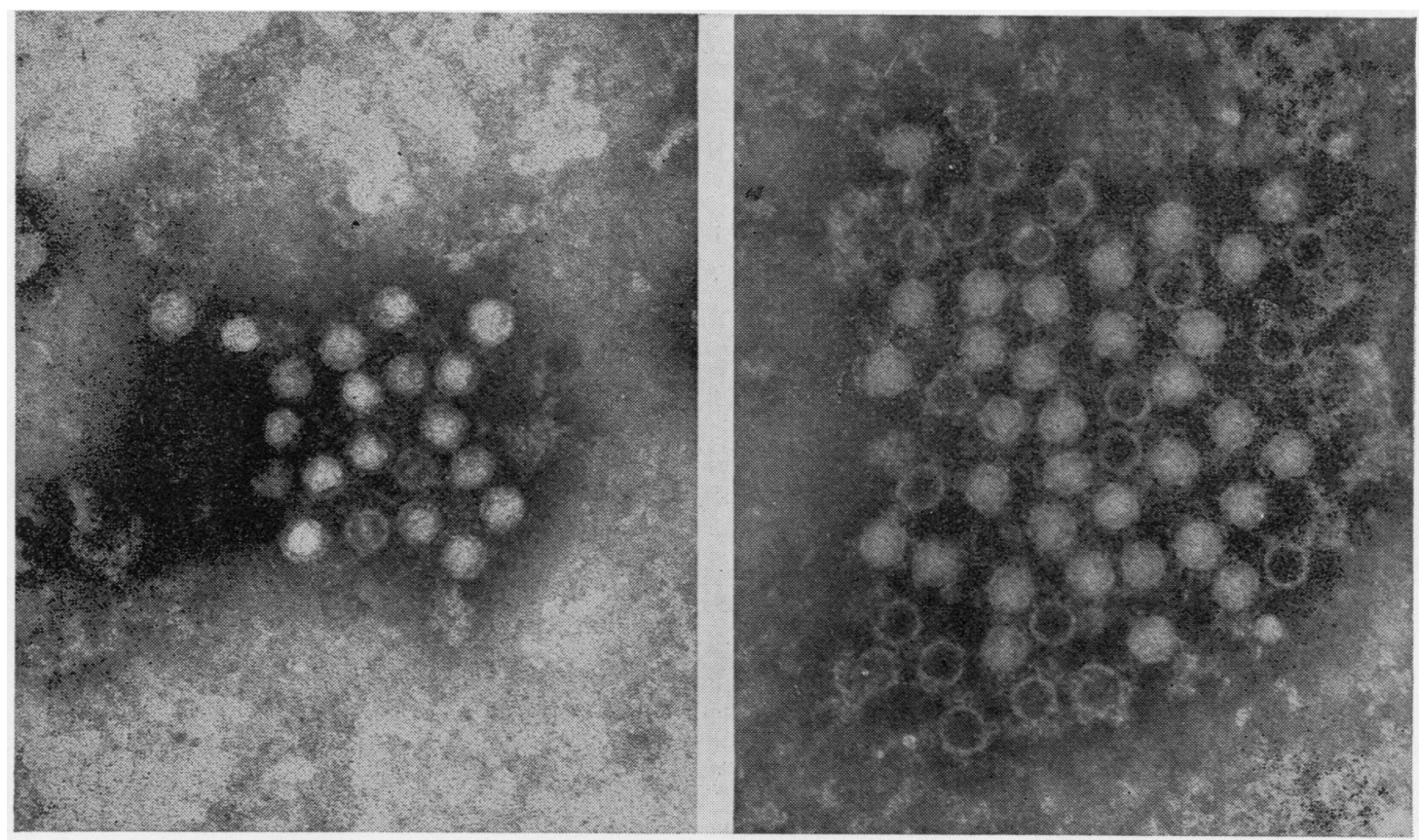

Fig 1 Electronmicrograph of HK 3751/71 virus (left) and Singapore 1971 virus (right) $\times 157500$. Note presence of empty particles especially in preparation of Singapore 1971 virus. 
fluid from HeLa tissue cultures inoculated with the Singapore 1970 and HK $3751 / 71$ viruses $\left(10^{7.5}\right.$ $\left.\mathrm{TCD}_{50} / \mathrm{ml}\right)$ was approximately 100 times greater than that of similar cultures infected with any of the other five viruses.

SHAPE AND SIZE OF VIRUS PARTICLE

When negatively stained with phosphotungstic acid both HK 3751/71 and Singapore 1971 viruses were shown to possess typical enterovirus morphology and measured on average $26.9 \mathrm{~nm}$ and $26.5 \mathrm{~nm}$ in diameter respectively (fig 1 ).

\section{PLAQUE MORPHOLOGY}

The small, irregular plaques produced by HK $3751 / 71$ and the Singapore 1971 viruses in HeLa cells under agar overlay were indistinguishable from one another (fig 2).

ETHER STABILITY

No significant loss of infectivity was observed when

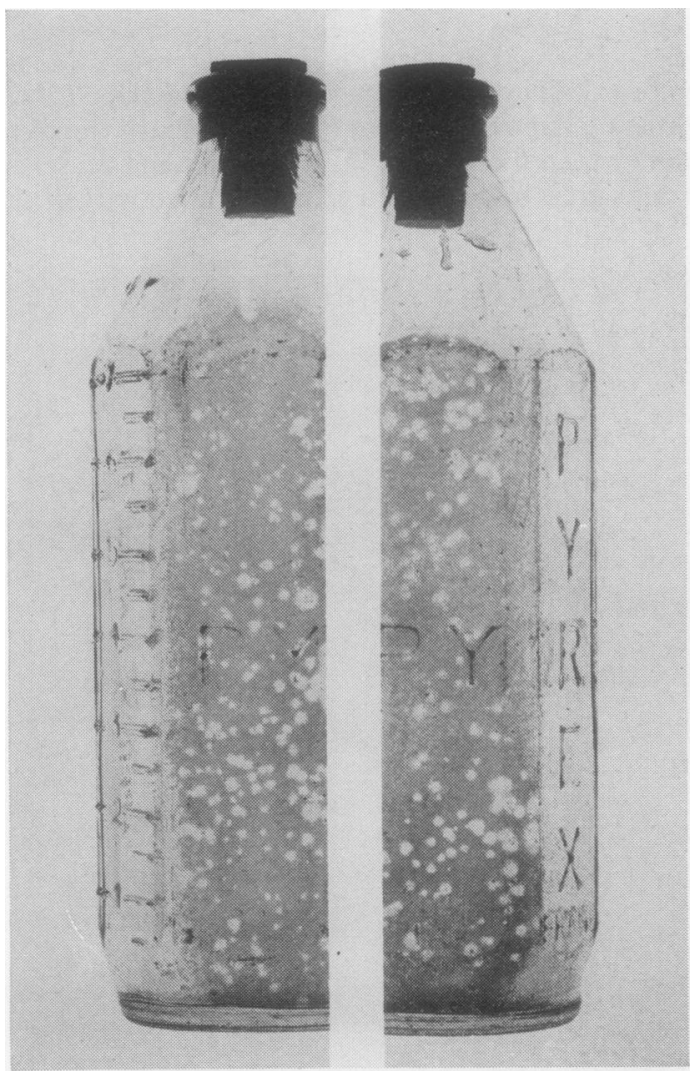

Fig 2 Plaques formed by Singapore 1971 virus (left) and HK 3751/71 virus (right) in HeLa cells under agar overlay. any of the seven viruses was treated with $20 \%$ ethyl ether for 18 hours at $4^{\circ} \mathrm{C}$.

\section{ACID STABILITY}

No significant loss of infectivity resulted from holding any of the seven viruses at $\mathrm{pH} 3$ for two hours.

\section{DEOXYCHOLATE SENSITIVITY}

No significant loss of infectivity was observed after any of the seven viruses was mixed with an equal volume of a 1:500 dilution of sodium deoxycholate and held at $37^{\circ} \mathrm{C}$ for one hour.

\section{5-IODODEOXYURIDINE SENSITIVITY}

No significant inhibition of growth was observed when any of the seven viruses was inoculated into tissue cultures maintained on a medium containing $0.02 \mathrm{mg}$ of 5 -iododeoxyuridine $/ \mathrm{ml}$.

\section{2-(HYDROXYBENZYL)-BENZIMIDAZOLE (HBB) SENSITIVITY}

No significant inhibition of virus multiplication was observed when either HK $3751 / 71$ or Singapore 1970 virus was titrated in tissue cultures maintained on a medium containing $219 \mu \mathrm{M}$ HBB whereas the growth of the other five viruses was markedly reduced or completely inhibited under such conditions.

\section{CATIONIC STABILIZATION}

The loss of infectivity which resulted from incubating a suspension of each of the seven viruses at $50^{\circ} \mathrm{C}$ for one hour was prevented when the suspending medium contained $\mathbf{M}$ magnesium chloride.

Parallel tests with sensitive and resistant control viruses were included in each experiment.

\section{BUOYANT DENSITY OF VIRUSES}

The buoyant density of each of the seven viruses was determined by placing a suspension of virus on the top of a gradient ranging from 20 to $40 \%$ D caesium chloride which was then spun at 35000 . rpm overnight at $+4^{\circ} \mathrm{C}$. The densities of the 15 to $N$ 20 fractions collected by piercing the bottom of the centrifuge tube were determined by refractometry $N$ and the infectivity by titration in tissue cultures. The $\underset{\omega}{ }$ buoyant density of each of the viruses was calculated $\bar{C}$ to be between 1.327 and $1.345 \mathrm{~g} / \mathrm{ml}$.

\section{HAEMAGGLUTINATION}

No viral haemagglutinin for $0.4 \%$ fowl or human red blood cells could be demonstrated at $4^{\circ} \mathrm{C}$, room temperature, or $37^{\circ} \mathrm{C}$ with any of the seven viruse s

PATHOGENICITY FOR SUCKLING MICE

Of a suspension of each of the seven viruses $0.02 \mathrm{ml}$ 
was inoculated intracerebrally and subcutaneously into each of six or more suckling mice less than 48 hours old. Only Singapore 1970 and HK 3751/71 viruses affected the mice consistently. These two viruses caused stunting of growth and paralysis in some of the newborn mice (fig 3) but HK 3751/71 produced a greater morbidity and mortality than the Singapore 1970 virus. The latter virus sometimes affected only one of a litter on primary inoculation but with a further passage an increasing proportion of the litter became paralysed. Virus was shown to be present in the brain as well as the torso of paralysed mice and paralysis usually occurred between the seventh and 14th days after inoculation but on occasion was delayed until the 21 st day. Paralysis was often limited to one limb, fore or hind, and could involve either the flexor or extensor group of muscles.

Sections of paralysed mice showed degeneration compatible with infection with a Coxsackie A virus.

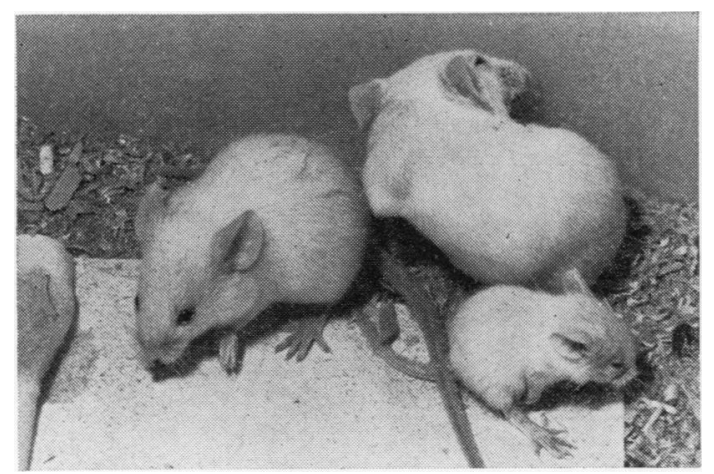

Fig 3 Three 30-day-old mice from the same litter inoculated with $H K 3751 / 71$ virus within 48 hours of birth. Mouse in background unaffected: stunting and bilateral paralysis of forelimbs of mouse in right foreground and paralysis of left forelimb of mouse in left foreground.

\section{SEROLOGY}

The neutralization of a representative virus from each group (Singapore 1970 and England 1971 viruses) could not be demonstrated in tissue culture with antisera to poliovirus types 1-3, echovirus types 1-7, 9, 11-34, Coxsackie A virus types 1-24, and Coxsackie B virus types 1-6. Singapore 1970 virus was not neutralized by antisera to Coxsackie A virus types 1-21 and 24 in suckling mice.

Antisera to each of the seven viruses were prepared in suckling mice by inoculating $0.02 \mathrm{ml}$ of virus suspension subcutaneously into each member of a litter. Three weeks later $1 \mathrm{ml}$ of virus suspension was given intraperitoneally to each of the surviving mice which were bled by cardiac puncture after a further seven to 10 days. Neutralization tests were performed by holding mixtures of equal volumes of virus suspension and doubling dilutions of serum at $37^{\circ} \mathrm{C}$ for one hour and then inoculating each of two tissue culture tubes with $0.2 \mathrm{ml}$ of the mixture containing 30-100 TCID $_{50}$ of virus. The results of the cross neutralization tests using the seven viruses and antisera produced against each strain are shown in table II. It can be seen that the Singapore 1970 and HK 3751/71 viruses are serologically related and distinct from the remaining five viruses which are antigenically similar to each other.

\section{Discussion}

All seven viruses have the characteristics of an enterovirus, ie, small viruses, insensitive to 5iododeoxyuridine, ether, deoxycholate, and having a buoyant density in caesium chloride of approximately $1.34 \mathrm{~g} / \mathrm{ml}$. The seven viruses can be divided into two groups on their growth in tissue culture, sensitivity to HBB and pathogenicity for suckling mice. Furthermore the two groups are serologically distinct although the members of each group are closely related antigenically if not identical.

The characteristics of the seven viruses, as determined in this study, are in general agreement with the findings of other workers (Yin-Murphy, and Lim 1972; Kono et al, 1972; Yin-Murphy, 1973). However, our observation of paralysis in suckling mice inoculated with the Singapore 1970 virus is contrary to the earlier report that these viruses are non-pathogenic

\begin{tabular}{|c|c|c|c|c|c|c|c|}
\hline \multirow[t]{2}{*}{ Virus } & \multicolumn{7}{|c|}{ Mouse Immune Sera } \\
\hline & Singapore 1970 & $H K 3571 / 71$ & $H K 3454 / 71$ & Japan 1971 & England 1971 & Singapore 1971 & Djakarta 1972 \\
\hline $\begin{array}{l}\text { Singapore } 1970 \\
\text { HK } 3571 / 71 \\
\text { HK } 3454 / 71 \\
\text { Japan } 1971 \\
\text { England } 1971 \\
\text { Singapore } 1971 \\
\text { Djakarta } 1972\end{array}$ & $\begin{array}{l}320^{1} \\
320 \\
<20 \\
<20 \\
<20 \\
<20 \\
<20\end{array}$ & $\begin{array}{r}80 \\
120 \\
<10 \\
<10 \\
<10 \\
<10 \\
<10\end{array}$ & $\begin{array}{l}<20 \\
<20 \\
1280 \\
1280 \\
1280 \\
2560 \\
3840\end{array}$ & $\begin{array}{r}<10 \\
<10 \\
40 \\
120 \\
160 \\
80 \\
40\end{array}$ & $\begin{array}{l}<20 \\
<20 \\
240 \\
320 \\
480 \\
320 \\
240\end{array}$ & $\begin{array}{l}<20 \\
<20 \\
1280 \\
1920 \\
1280 \\
2560 \\
1280\end{array}$ & $\begin{array}{l}<20 \\
<20 \\
240 \\
320 \\
640 \\
320 \\
320\end{array}$ \\
\hline
\end{tabular}

Table II Antigenic relationships between seven viruses isolated from cases of acute haemorrhagic conjunctivitis 
for this animal (Yin-Murphy, 1972). We have noted a variation in the ability of strains from this epidemic to paralyse suckling mice and the selection of different representative strains may well account for this discrepancy. Similarly the ease with which different strains of the Singapore 1970 virus adapt to cultures of monkey kidney varies. Commonly one or more blind passes are required and it is unlikely that adaptation can be demonstrated within 14 days of inoculation (Yin-Murphy, 1972) unless cultures from cynomolgus monkeys are more sensitive than those from rhesus monkeys.

Antisera to the known polio, Coxsackie, and echo viruses failed to neutralize a representative virus from each group and we were unable to confirm that antiserum to Coxsackie virus type $A_{19}$ would inhibit multiplication of either virus in tissue culture or the Singapore 1970 virus in suckling mice (Bourdieu, 1973). It would seem probable therefore, that the viruses studied are representatives of two new enterovirus types but it will be necessary to test all the prototype enteroviruses with antisera against representatives of each of the two groups to be certain they are not prime strains of established serotypes.
We are grateful to Dr Anne Field and Mr A. A. $\stackrel{0}{\frac{0}{2}}$ Porter of the Virus Reference Laboratory for the으. electron micrographs and measurement of virus $\Rightarrow$ particles and to Colonel E. E. Vella, RAMC, Millbank, for sectioning paralysed mice and his reports? on the histology.

\section{References}

Bourdieu, J. P. (1973). A. propos de l'épidémie de conjunctiviteobservée au Maroc en 1971. Maroc méd., 53, 45-60.

Conant, R. M., and Hamparian, V. V. (1968). Rhinoviruses: basis for a numbering system 1 . HeLa cells for propagation and sero- $\bigcirc$ logical procedures. J. Immunol., 100, 107-113.

Higgins, P. G., and Scott, R. J. D. (1973). The isolation of entero- $\vec{\omega}$ viruses from cases of acute conjunctivitis. J. clin. Path., 26, 706-711.

Jones, B. R. (1972). Epidermic haemorrhagic conjunctivitis in Londoñ 1971: a conjunctival piconavirus infection. Trans. ophthal. Soc. Ny

Kono, R., Sasagawa, A., Ishii, K., Ochi, M., Matsumiya, H., i Uchida, Y., Kameyama, K., Kaneko, M., Sugiura, S., andi Sakurai, N. (1972). Pandemic of new type of conjunctivitis. N Lancet, 1, 1191-1194.

Lim, K. H., and Yin-Murphy, M. (1971). An epidemic of conjuncti-음 vitis in Singapore in 1970. Singapore med. J., 12, 247-249.

Lim, K. H., and Yin-Murphy, M. (1973). Epidemic conjunctivitis in Singapore in 1970 and 1971. Singapore med. J., 14, 86-89.

Yin-Murphy, M. (1972). An epidemic of piconavirus conjunctivitis in Singapore. S.E. Asian J. trop. Med. publ. Hlth, 3, 303-309.

Yin-Murphy, M. (1973). The picornaviruses of acute haemorrhagic $\overrightarrow{0}$ conjunctivitis: a comparative study. S.E. Asian J. trop. Med. $\perp$ publ. Hlth, 4, 305-310.

Yin-Murphy, M., and Lim, K. H. (1972). Picornavirus epidemic conjunctivitis in Singapore. Lancet, 2, 857-858. 